\title{
Economic Optimum of Thermal Insulating Layer for External Wall of Brick
}

\author{
Jozsef Nyers
}

Obuda University Budapest, Becsi ut 96, 1034 Budapest, Hungary

Subotica Tech, Marko Oreskovic 16, 24000 Subotica, Serbia

e-mail : jnyers@vts.su.ac.rs

\section{Slavica Tomić}

Faculty of Economics Subotica, Segedinski put 9-11,24000 Subotica, Serbia e-mail : tomics@ef.uns.ac.rs

\section{Arpad Nyers}

Subotica Tech, Marko Oreskovic 16, 24000 Subotica, Serbia e-mail : nyarp@vts.su.ac.rs

\begin{abstract}
This paper analyzes the technical and economic optimum thickness of a thermal insulation layer of an external wall. The observed wall was made of brick and the used thermal insulation material was polystyrene. The heat transfer through the wall takes place in the stationary regime. The mathematical model consists of algebraic equations for investment, exploitation and saving. The graph-analytical method was applied to solve the mathematical model. The applied optimization criterion is the minimum payback period of the investment. The numerical results obtained by the simulation are presented graphically. The optimum thickness of the thermal insulation layer can be seen from the diagram. Based on current prices in Serbia 2013 the techno-economical optimum thickness of thermal insulation layer (polystyrene) is $9 \mathrm{~cm}$. The minimum payback period is 1.96 years.
\end{abstract}

Keywords: optimum; mathematical model; thermal insulation; criterion

\section{Nomenclature}

$q \quad$ heat flux per unit area $\left[W / m^{2}\right]$

$\mathrm{Q} \quad$ heat per unit area per year $\left[W h / \mathrm{m}^{2} /\right.$ year $]$

$\Delta Q \quad$ heat difference per unit area per year $\left[\mathrm{Wh} / \mathrm{m}^{2} /\right.$ year $]$

$\alpha \quad$ convective heat transfer coefficient $\left[\mathrm{W} / \mathrm{m}^{2} /{ }^{\circ} \mathrm{C}\right]$ 
$\lambda \quad$ conductive heat transfer coefficient $\left[\mathrm{W} / \mathrm{m} /{ }^{\circ} \mathrm{C}\right]$

$k \quad$ overall heat transfer coefficient $\left[W / m^{2} /{ }^{\circ} \mathrm{C}\right]$

$t \quad$ temperature $\left[{ }^{\circ} \mathrm{C}\right]$

$\Delta t \quad$ temperature difference $\left[{ }^{\circ} \mathrm{C}\right]$

$\tau \quad$ time period per year [h/year]

$\delta \quad$ thickness of thermal isolator layer

Subscripts and superscripts

i input

o output

m middle

\section{Introduction}

Serbia now has the lowest level of energy efficiency in Europe. It is located on the bottom of the list among the countries that use energy rationally. Buildings in Serbia are huge energy consumers. The average consumption of final energy in buildings of the European Union in thermal purposes is $138 \mathrm{kWh} / \mathrm{m}^{2}$.In most developed countries the tendency is to reach a value below $70 \mathrm{kWh} / \mathrm{m}^{2}$. In Serbia, it is about $200 \mathrm{kWh} / \mathrm{m}^{2}$. Therefore, the reduction of energy consumption and improvement of energy efficiency is necessary.

The effectiveness of this study is an energy-economic category. Achieving maximum results with minimal investment is a general principle of economic efficiency. It is necessary to increase efficiency and reduce costs, reduce the harmful impact on the environment. The solution reduces the use of natural resources, less waste, the air is less polluted. In this way, the demanding task of formula $3 \mathrm{E}$ - energy, economy, ecology can be realized.

Respecting the principles of energy efficiency has become a liability, not the individual's choice. The introduction of the directive on the energy performance of buildings (EPBD - Energy Performance of Buildings Directive ), the European Union is trying to reduce the amount of energy used in buildings.

Directive EPBD includes the adoption of appropriate regulations, incorporated in the legislation of Serbia. The study of energy efficiency dating September 2012 has become a legal obligation. This means that all houses built according to this law, when used, will consume less energy. But new buildings make up a small percentage of the total amount of constructed buildings.

From the aspect of energy saving, it is important to carry out the reconstruction of the existing buildings. $50 \%$ of these buildings was built before the existence of any regulations on thermal protection. 
There are numerous studies which were performed on the definition of the optimum thermal insulation thickness[3]. Some of them are based on the degreedays method.This is calculated as the difference between the base temperature and the mean outdoor air temperature. Betul Bektas, Ayca Aytac Gulten and Teoman Aksoy are investigating the effects of the wall type and degree day values on the optimum insulation thicknesses for different insulation materials. The calculation was carried out for four different cities in different climate zones in Turkey. The cost of fuel decreases with the increase in insulation thickness. The total cost is the sum of the cost of fuel and insulation material. The optimum insulation thickness is determined as the minimum of the total cost curve.[4] A number of other authors also used the same "economic energy" method, including Bolatturk A,.K. Çomaklı, B. Yüksel,. J. Yu, C. Yang, L. Tian, D. Liao [5], [6], [7]. Several studies used the degree time method with financial components-market discount rate (for the value of money), the inflation rate (for the energy cost), to calculate the net energy savings [4], [8]. [9]. Dynamic transient models based on numerical methods were also applied in the literature [10], [11].

From the point of view the economic-energy efficiency of buildings, it is primary to use the thermal insulation layer to cover all external surfaces. The thermal insulation layer greatly reduces building heat loss. The reduction of losses depends on the thickness of the thermal insulation layer.

Increasing the thermal insulation layer increases the investment costs, but also reduces costs in the exploitation. Costs for investment and exploitation have opposite tendencies. Thus it follows, there is the techno-economic optimum of thermal insulation layer.

The optimum can be found by applying appropriate mathematical models and an efficient mathematical method. From the standpoint of analysis, the important issue is the way results are presented. One of the convenient forms of representation is the graphic display of results. The graphics show the solution visually and trends of change solutions.

This paper analyzes the economic optimum thickness of the thermal insulation layer of the external wall of the brick. The analysis provides a mathematical model attached. The model is composed of functions to describe the cost of investment, exploitation and saving function. In the functions, the values are expressed in Euros. The independent variables are the thickness of thermal insulation layers and the payback period of the investment.

In order to solve the model's equations the graph-analytical method is applied.The pure analytical method is applicable but very complicated. Solutions are shown in the accompanying graphs for the cost of investment, exploitation and savings over the exploration and the payback period of the investment. The graphs show the optimum thickness of the thermal insulation layer. The optimum is obtained by equating functions for investment and saving functions during operation. The optimal solution thickness of thermal insulation layer is obtained only after the 
determination and replacement of the optimum for the minimum payback period in the equation.

Based on the application of the mathematical model and graph-analytical mathematical procedure it can be concluded that in Serbia, in 2013, the optimum thickness of the thermal insulation layer is $9 \mathrm{~cm}$ if the minimum payback period of the investment is 1.98 years and if the heat source used is electric energy with the price of $0,08 \mathrm{eu} / \mathrm{kWh}$.

\section{The Physical Model}

The observed physical system for techno-economic optimization consists of an outer wall with and without thermal insulation. The static part of the observed wall was made of $25-\mathrm{cm}$-thick bricks and thermal insulation of the polystyrene (styrofoam).

From the standpoint of thermal calculation transmission heat losses observed over the outer wall, there are two layers that produce heat-resistance, thermal insulation and brick. The transmission heat loss depends on the thickness and physical characteristics of the layers.

The ventilation heat loss is not taken into account because it does not affect the techno-economic optimum of the thermal insulation layer's thickness. These losses depend on the size of the gap sealing windows and external doors.
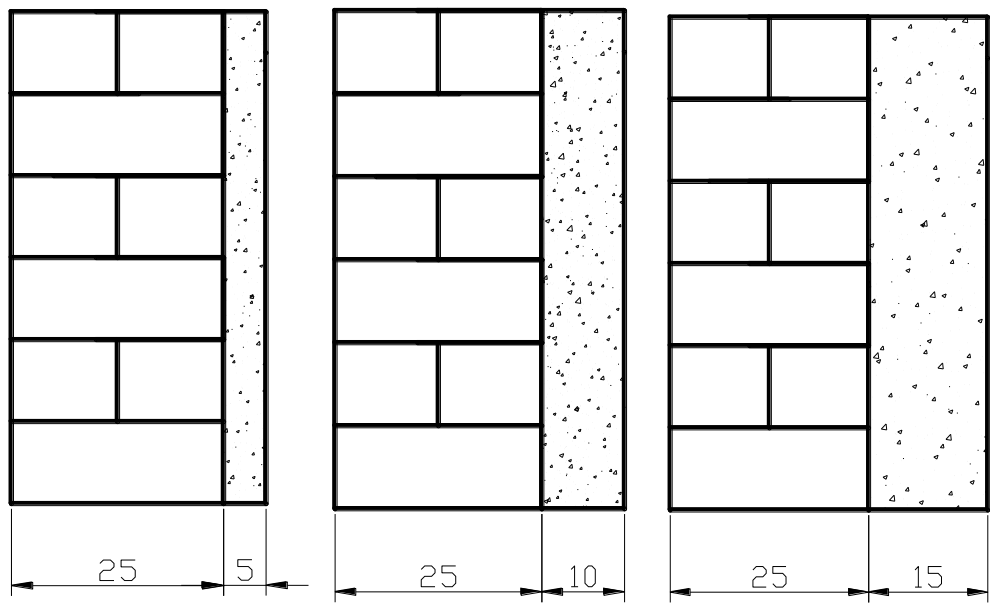

Figure 1

The cross section of the external walls of $25-\mathrm{cm}$-thick bricks with thermal insulation layer thickness of $=5 \mathrm{~cm}, 10 \mathrm{~cm}, 15 \mathrm{~cm}$ 


\section{The Energy Part of the Mathematical Model}

\subsection{Transmission Heat Losses of External Walls}

\subsubsection{The Mean Heat Flux through the External Walls per Unit Area for} the Heating Season

$q_{m}=k \cdot \Delta t_{m}\left[W / m^{2}\right]$

where are:

- overall heat transfer coefficient $\left[W / m^{2} \rho C\right]$

$k=\frac{1}{\frac{1}{\alpha i}+\sum \frac{\delta}{\lambda}+\frac{1}{\alpha o}}\left[W / m^{2} \rho C\right]$

- medium temperature difference between the temperature of the internal $t_{i}$ and the mean outside air temperature $t_{m o}$ for the heating season

$\Delta t_{m}=t_{i}-t_{m o}\left[{ }^{o} C\right]$

\subsubsection{The Amount of Heat of the Heating Season per Unit Area}

$Q=q_{m} \cdot \tau$

$Q=k \cdot \Delta t_{m} \cdot \tau\left[W h / m^{2} /\right.$ year $]$

where the following are denoted:

- duration of the heating season in hour $\tau_{\text {[h/year] }}$

\subsubsection{Amount of Heating Energy for the Heating Season per Area of External Wall and for Various Thermal Insulation Layer Thickness $\delta$}

for $\delta=0 \mathrm{~cm} Q_{(0)}=k_{(0)} \cdot \Delta t_{m} \cdot \tau$

for $\delta=5 \mathrm{~cm} Q_{(5)}=k_{(5)} \cdot \Delta t_{m} \cdot \tau$

for $\delta=10 \mathrm{~cm} Q_{(10)}=k_{(10)} \cdot \Delta t_{m} \cdot \tau$

for $\delta=15 \mathrm{~cm} Q_{(15)}=k_{(15)} \cdot \Delta t_{m} \cdot \tau$

In general, the amount of heating energy for heating season per area as a function of thickness of insulating layer $\delta$

$Q_{(\delta)}=k_{(\delta)} \cdot \Delta t_{m} \cdot \tau \quad \delta=0,5,10,15 \mathrm{~cm}$ 
3.1.4 Amount of Saved Heat between the Thermal Insulated and Thermal Un-insulated External Wall of the Heating Season per Unit Area

$\Delta Q_{(5)}=Q_{(0)}-Q_{(5)}$

$\Delta Q_{(5)}=k_{(0)} \cdot \Delta t_{m} \cdot \tau-k_{(5)} \cdot \Delta t_{m} \cdot \tau=\left(k_{(0)}-k_{(5)}\right) \cdot \Delta t_{m} \cdot \tau$

$\Delta Q_{(5)}=\left(k_{(0)}-k_{(5)}\right) \cdot \Delta t_{m} \cdot \tau$

In general, the amount of heat

$\Delta Q_{(\delta)}=\left(k_{(0)}-k_{(\delta)}\right) \cdot \Delta t_{m} \cdot \tau\left[\mathrm{Wh} / \mathrm{m}^{2} /\right.$ year $] \quad \delta=0,5,10,15 \mathrm{~cm} .$.

3.1.5 Amount of Saved Heat for the Heating Season per Unit Area in Continuous Form

$\Delta Q_{(\delta)}=\Delta k_{(\delta)} \cdot \Delta t_{m} \cdot \tau\left[W h / m^{2} /\right.$ year $]$

where:

- The difference of heat transfer coefficient

$\Delta k_{(\delta)}=\frac{1}{\frac{1}{\alpha_{i}}+\Sigma \frac{\delta}{\lambda}+\frac{\delta=0}{\lambda}+\frac{1}{\alpha_{o}}}-\frac{1}{\frac{1}{\alpha_{i}}+\Sigma \frac{\delta}{\lambda}+\frac{\delta>0 \ldots . . n}{\lambda}+\frac{1}{\alpha_{o}}} \delta>0 \ldots \ldots \ldots . . n$

$\left[W / m^{2} \rho C\right]$

\section{Economic Part of the Mathematical Model}

\subsection{The Cost of Heating in Euros as a Function of Thermal Insulation per Unit Area for the Heating Season}

$f_{h}=\sum_{0}^{n} Q_{(\delta)} \cdot e\left[e u / m^{2} /\right.$ year $]$

\subsection{Economic Savings in Euros as a Function of Thermal Insulation per Unit Area for the Heating Season \\ $f_{s}=\sum_{0}^{n} \Delta Q_{(\delta)} \cdot e\left[e u / m^{2} /\right.$ year $]$}

where: e $[\mathrm{eu} / \mathrm{kW}]$ - unit price of energy for heating 


\section{Investment in Thermal Insulation}

\subsection{The Function of Investment Depending on the Thickness of the Thermal Insulation Layer( $\delta$ )}

$f_{i}=C_{\text {isol }}(\delta)+C_{\text {tiple }}(\delta)+C_{\text {net }}+C_{\text {glue }}+C_{\text {pay }}\left[e u / m^{2}\right]$

The price of thermal insulation and the price of thermal insulation dowels depend on the thickness of the thermal insulating layer. Other terms are independent of the layer thickness.

\subsubsection{The Constant Part of the Function of Investment}

$C=C_{\text {net }}+C_{\text {glue }}+C_{\text {pay }}\left[\mathrm{eu} / \mathrm{m}^{2}\right]$

where:

- Price of fiber glass net per $\mathrm{m}^{2}$

$C_{\text {net }}\left[\mathrm{eu} / \mathrm{m}^{2}\right]$

- Price of glue for polystyrene per $\mathrm{m}^{2}$

$C_{\text {glue }}=C_{\text {glue }, \mathrm{kg}}[\mathrm{eu} / \mathrm{kg}] \times \mathrm{n}\left[\mathrm{kg} / \mathrm{m}^{2}\right]$

- price of glue per kilogram

$C_{\text {glue }, k g} \cdot[\mathrm{eu} / \mathrm{kg}]$

- consumption of glue per $\mathrm{m}^{2}$

$\mathrm{n}\left[\mathrm{kg} / \mathrm{m}^{2}\right]$

- Price of labor per $\mathrm{m}^{2}$

$\mathrm{C}_{\text {pay }}\left[\mathrm{eu} / \mathrm{m}^{2}\right]$

\subsection{Investment Function in the Final Form}

$f_{i}=C_{\text {isol }}(\delta)+C_{\text {tiple }}(\delta)+C\left[\mathrm{eu} / \mathrm{m}^{2}\right]$

where:

- Price of thermal insulation per $\mathrm{m}^{2}$ depending on the thickness of insulating layer

$C_{\text {isol }}(\delta)=C_{\text {isol, } m}\left[\mathrm{eu} / \mathrm{m}^{3}\right] \times C_{m}\left[\mathrm{~m}^{3} / \mathrm{m}^{2} \mathrm{~m}\right] \times \delta[\mathrm{m}]$

- $C_{i s o l, m}\left[e u / m^{3}\right]$ Price of thermal insulation

- $C_{m}\left[\mathrm{~m}^{3} / \mathrm{m}^{2} \mathrm{~m}\right]$ Number of $\mathrm{m}^{2}$ in $\mathrm{m}^{3}$ cubic meter depending on $\delta$ of thickness

- $\delta[m]$ Thickness of thermal insulation

- $C_{\text {tiple }}$ Price of dowels per $\mathrm{m}^{2}$ depending on the thickness of the insulating layer 


\section{The Simulation}

\subsection{About the Simulation}

The simulation to determine the optimal thickness of thermal insulating layer is made based on the techno-economic situation in Serbia in 2013. The static part of the outer wall is made of 25 -cm-thick bricks and the material of thermal insulation is polystyrene. The energy source of heat is electrical energy. The optimization criterion is the minimum payback period of investment.

\subsection{Data for the Simulation}

- thickness of the brick wall $\delta=0.25 \mathrm{~m}$,

- thickness of the polystyrene to the thermal isolation $\delta=1 ; 2 ; 3 ; \ldots .20 \mathrm{~cm}$,

- coefficient of heat conduction for the brick wall $\lambda=0.5 \mathrm{~W} / \mathrm{m} /{ }^{\circ} \mathrm{C}$,

- coefficient of heat conduction of polystyrene $\lambda=0.05 \mathrm{~W} / \mathrm{m} /{ }^{\circ} \mathrm{C}$,

- convection heat transfer coefficient for the indoor air $\alpha_{i}=8 \mathrm{~W} / \mathrm{m}^{2} /{ }^{\circ} \mathrm{C}$,

- convection heat transfer coefficient for the outside air $\alpha_{o}=20 \mathrm{~W} / \mathrm{m}^{2} /{ }^{\circ} \mathrm{C}$,

- internal temperature $\mathrm{t}_{\mathrm{i}}=20^{\circ} \mathrm{C}$,

- medium outdoor temperature for heating season $\mathrm{t}_{\mathrm{m}}=4{ }^{\circ} \mathrm{C}$,

- the duration of the heating season 200 days/year x $24 \mathrm{~h} /$ day $=4800 \mathrm{~h} /$ year,

- price of polystyrene $40 \mathrm{eu} / \mathrm{m}^{3}$ or $4 \mathrm{eu} / \mathrm{m}^{2}$ for the thickness of $0.1 \mathrm{~m}, 2 \mathrm{eu} / \mathrm{m}^{2}$ for, the thickness of $0.05 \mathrm{~m}, 6 \mathrm{eu} / \mathrm{m}^{2}$ for the thickness $0.15 \mathrm{~m}$,

- price of glue $5 \mathrm{eu} / 25 \mathrm{~kg}$ or $0.2 \mathrm{eu} / \mathrm{kg}$,

- consumption of glue $7 \mathrm{~kg} / \mathrm{m}^{2}$,

- price dowels for polystyrene of $5 \mathrm{~cm}, 10 \mathrm{~cm}, 15 \mathrm{~cm}$,

- price of labor for the installation of thermal insulating layer $6 \mathrm{eu} / \mathrm{m}^{2}$.

\subsection{Functions of Simulation}

\subsubsection{The Function of Economic Savings with Data}

$$
f_{s}=\Delta k_{(\delta)} \cdot \tau \cdot e\left[W h / m^{2} / g o d\right]
$$

- The difference of the overall coefficient of heat transfer through the wall 


$$
\Delta k_{(\delta)}=\frac{1}{\frac{1}{20}+\frac{0.25}{0.5}+\frac{1}{8}}-\frac{1}{\frac{1}{20}+\frac{0.25}{0.5}+\frac{\delta}{0.05}+\frac{1}{8}}
$$

- The mean temperature difference between the indoor air temperature and the mean temperature of the outside air during the heating season can be seen below

$$
\Delta t_{m}=t_{i}-t_{o}=20-4=16^{\circ} \mathrm{C}
$$

- Period of the heating season

$$
\tau=200 \text { day } / \text { year } \cdot 24 \mathrm{~h} / \text { year }=4800 \text { [h/ year ] }
$$

- mean unit price of electric energy in Serbia in 2013

$$
e=0.8[\mathrm{eu} / \mathrm{kWh}]
$$

\subsubsection{The Function of Investments in the Thermal Insulation, with Data}

$f_{i}=C_{\text {isol }}(\delta)+C_{\text {tiple }}(\delta)+C_{\text {net }}+C_{\text {glue }}+C_{\text {pay }}\left[\mathrm{eu} / \mathrm{m}^{2}\right]$

$f_{i}=40 \mathrm{eu} / \mathrm{m}^{3} \times \delta m+0+2\left[\mathrm{eu} / \mathrm{m}^{2}\right]+1.4 \mathrm{eu} / \mathrm{m}^{2}+6\left[\mathrm{eu} / \mathrm{m}^{2}\right]\left[\mathrm{eu} / \mathrm{m}^{2}\right]$

where is the following are included:

- Price of fiberglass net per $\mathrm{m}^{2} \quad C_{n e t}=2\left[\mathrm{eu} / \mathrm{m}^{2}\right]$

- Price of glue per $\mathrm{m}^{2} \quad C_{\text {glue }}=5 \mathrm{eu} / 25 \mathrm{~kg} * 7 \mathrm{~kg} / \mathrm{m}^{2}=1.4\left[\mathrm{eu} / \mathrm{m}^{2}\right]$

- Price of labor per $\mathrm{m}^{2} \quad C_{\text {pay }}=6\left[\mathrm{eu} / \mathrm{m}^{2}\right]$

- Price of thermal insulation per $\mathrm{m}^{3}$ $C_{\text {isol }}(\delta)=40\left[\mathrm{eu} / \mathrm{m}^{3}\right]$

- Price of dowels can be neglected due to the very low values. $C_{\text {tiple }}(\delta)=0$

\section{Mathematical Optimization Procedure}

The mathematical model consists of two equations which are related through the thickness of thermal insulating layer. The equation for investment is linear while for the savings it is exponential. The economic optimum thickness of the insulating layer can be obtained using the analytical or graphical procedure.

\subsection{Analytical Optimization Procedure}

The analytical solution of the optimal thermal insulating layer in terms of the economy is obtained by equating the functions of investment and savings function. 
$f_{i}=C_{\text {isol }}(\delta)+C_{\text {tiple }}(\delta)+C_{\text {net }}+C_{\text {glue }}+C_{\text {pay }}$

$f_{s}=\Delta k(\delta) \cdot \tau \cdot e$

$f i=f s$

After the replacement, the equation of investment is obtained

$f=C_{\text {isol }}(\delta)+C_{\text {tiple }}(\delta)+C_{n e t}+C_{\text {glue }}+C_{\text {pay }}=0$

The resulting equation (36) contains the three independent variables: The thickness of the insulating layer, the certain time period, the unit price of energy. The equation can be solved by one or the other of the third variable.

The economic optimum thickness of the thermal insulating layer is obtained by the minimum payback period. The analytical determination of the minimum payback period is possible by means of the first partial differencing of the implicit function (37), by the thickness of the thermal insulating layer. The first differential is equal to zero.

$\partial f(\rho, \tau) / \partial \rho=0$

From the equation (38) the minimum payback period is expressed. The result of the minimum payback period is replaced in the equation (36) and after an adjustment, the optimum thickness of thermal insulating layer may be determined.

From the above it can be seen that the analytical process is quite complicated and the obtained solution is analytic. For the analysis of the solutions in a wide range of changes in thickness of thermal insulating layers must work in graphics.

It follows from the foregoing that the complete process optimization works better in numerical-graphical form.

\subsection{Numerical - Graphical Optimization Procedure}

The numerical - graphical optimization procedure is much more appropriate than the analytical procedure. The solution is obtained in numerical form and after that, the solution is displayed in graphical form in the coordinate system. The analysis is visual, the graphics show the tendency of change in the investment, the savings, the cost of heating as a function of the wide range of changes of the thermal insulating layer's thickness.

The chart shows the optimum thickness of the thermal insulating layer and the minimum payback period of the investment.

The realization of the simulation is as follows: an algorithm was created for the numerical solution of the mathematical model and the algorithm is implemented in one of the numerical and mathematical package. The packages are supplied with graphics support for displaying numerical results.

In this case the algorithm for the numerical solution of function (36) is implemented in the mathematical package Matlab. 


\section{Results}

Using simulation the obtained numerical results are presented graphically in Figures 2 and 3.

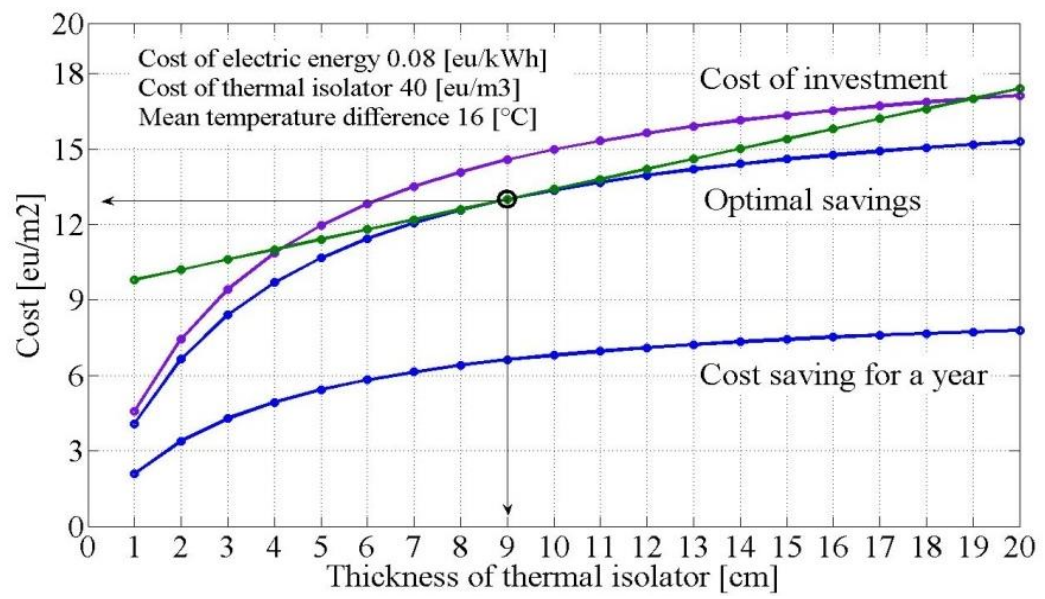

Figure 2

The function of investment, green straight line. Savings function is exponential blue-line and the investment return period of 1 year, from 1.98 years and 2.2 years.

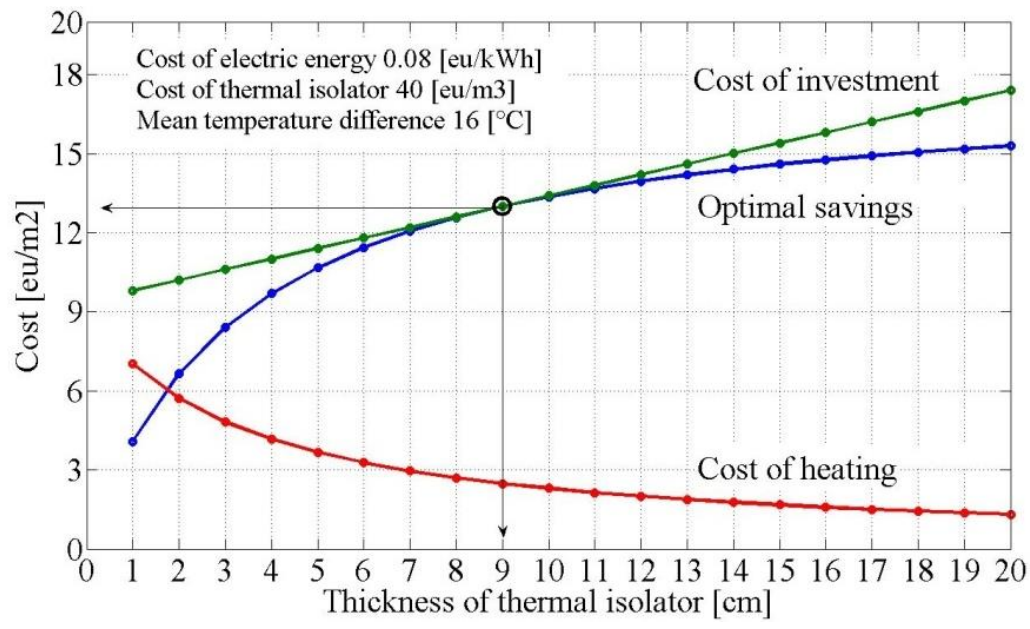

Figure 3

The optimum thickness of the thermal insulating layer in a joint investment function point, straight line and savings function exponential-line for a minimum payback period. The hyperbolic red line represents the cost of exploitation 


\section{Discussion}

\section{Discussion of the Mathematical Model}

The mathematical model consists of the energy and economic part.

The energy of the model includes the equation of the heat loss through the wall and the equation of saving heat by using the thermal insulating layer. These algebraic equations are two dependent and two independent variables. The dependent variables are the amount of heat and the amount of heat saving, while the independent variables are the thickness of the thermal insulating layer, and the time of heating.

The economic part of the model includes a function of the cost of heating, the function of financial savings and the function of the balance between the costs and savings for a certain time period. These algebraic equations are two dependent and three independent variables. The dependent variables are the cost heating and financial savings and independent variables are the thickness of the thermal insulating layer, the observed time and energy prices.

In this paper, for a given techno-economic structure, the conditions of optimality are: 1 . the investment equal to savings. 2 . the payback period is minimal.

\section{Discussion of Numerical Procedure}

During the mathematical description of the defined problems, the authors tended to have a mathematical model that accurately describe the behavior of analyzed physical system.

The value-price of the model's elements is taken from the practice based on the data obtained from the market.

In order to solve the mathematical model the graphical-numerical procedure was chosen. The advantage of the procedure is the representation of the numerical results from the simulation in graphical form. Graphs are highly suitable for the analysis of the problem, because they provide a very wide range of changes of the independent variables and analyze the behavior of the observed dependent variables. The algorithms of mathematical models are realized in the mathematical-graphical package Matlab.

\section{Discussion of Results Obtained by Simulation}

The simulation was performed in order to obtain the optimum of thickness of the thermal insulation layer for the defined technical and economic conditions in Serbia in 2013. From a technical aspect, the examined outside wall is covered with thermal insulation of polystyrene, while from an economic point of view the fixed and variable costs are considered. All economic data are valid for the year 2013.

Figure 2. above shows the function of investment and savings functions for the reference period of 1 year; 1.96 years and 2.2 years. It can be noted that there is only one common point or value of function of investment and savings for the 
payback period of 1.96 years. The common point defines the optimal value of the thickness of polystyrene which is $9 \mathrm{~cm}$ if the payback period is 1.96 years for the defined technical and economic conditions in Serbia.

The time of 1.96 years is the minimum payback period for the defined technical and economic conditions in Serbia in 2013. Only the minimal payback period provides the common solution of investment function and savings function. For the observed period of 1 year there is no solution, the functions pass each other, thus the requirement of a minimum period of payback period is not fulfilled.

For the period of 2.2 years the saving function intersects the line of investments in two points. The two solutions are obtained for the thickness of polystyrene. What is common in these two solutions is that their pay back period is the same for 2.2 years not least for 1.96 years.

The minimum payback period is obtained analytically, or graph-analytically. Analytically it is the first derivative of the function (36) which is equal to zero. Graph-analytically the minimum is obtained by moving closer the graphics savings while not touching the line of investment.

Figure 3 shows the functions of investment, savings and the cost of heating per square meter of external wall insulation with polystyrene. Graphs apply to the technical and economic conditions for Serbia in 2013. The common point of the lines of investment and savings defined the optimum thickness of polystyrene for a minimum payback period.

In the graph of the cost functions it can be seen that the optimum thickness of 9 $\mathrm{cm}$ polystyrene cost of heating per $\mathrm{m}^{2}$ of external thermal insulated brick wall is $2.5 \mathrm{eu} / \mathrm{m}^{2}$, the noninsulated wall is $9 \mathrm{eu} / \mathrm{m}^{2}$. The saving is $6.5 \mathrm{eu} / \mathrm{m}^{2}$ while the payback period is 1.96 years in Serbia in 2013, if the heat source used is electric energy with a price of $0.08 \mathrm{eu} / \mathrm{kWh}$.

\section{References}

[1] Asiye Aslan, Bedri Yuksel, Tugrul Akyol: Energy Analysis of Different Types of Buildings in Gonen Geothermal District Heating System. Applied Thermal Engineering, Vol. 31, Issues 14-15, October 2011, pp. 2726-2734

[2] Betul Bektas Ekici, Ayca Aytac Gulten, U. Teoman Aksoy: A Study on the Optimum Insulation Thicknesses of Various Types of External Walls with Respect to Different Materials, Fuels and Climate Zones in Turkey. Applied Energy, Vol. 92, April 2012, pp. 211-217

[3] Ray Galvin: Thermal Upgrades of Existing Homes in Germany: The Building Code, Subsidies, and Economic Efficiency. Energy and Buildings, Vol. 42, Issue 6, June 2010, pp. 834-844

[4] Omer Kaynakli: A Review of the Economical and Optimum Thermal Insulation Thickness for Building Applications. Renewable and Sustainable Energy Reviews, Vol. 16, Issue 1, January 2012, pp. 415-425 
[5] R. Pacheco, J. Ordonez, G. Martinez: Energy Efficient Design of Building: A Review Renewable and Sustainable Energy. Reviews, Vol. 16, Issue 6, August 2012, pp. 3559-3573

[6] Soteris A. Kalogirou, George Florides, Savvas Tassou: Energy Analysis of Buildings Employing Thermal Mass in Cyprus. Renewable Energy, Vol. 27, Issue 3, November 2002, pp. 353-36

[7] Meral Ozel: Cost Analysis for Optimum Thicknesses and Environmental Impacts of Different Insulation Materials. Energy and Buildings, Vol. 49, June 2012, pp. 552-559

[8] Surapong Chiraratananon, Vu Duc Hien: Thermal Performance and Cost Effectiveness of Massive Walls under Thai Climate, Energy and Buildings, Vol. 43, Issue 7, July 2011, pp. 1655-166

[9] Meral Ozel: Effect of Wall Orientation on the Optimum Insulation Thickness by Using a Dynamic Method. Applied Energy, Vol. 88, Issue 7, July 2011, pp. 2429-243

[10] Bolatturk A: Determination of Optimum Insulation Thickness for Building Walls with Respect to Various Fuels and Climate Zones in Turkey (2006) Applied Thermal Engineering, 26(11-12), pp. 1301-1309

[11] K. Çomaklı, B. Yüksel: Optimum Insulation Thickness of External Walls for Energy Saving, Applied Thermal Engineering, 23 (2003) pp. 473-479

[12] J. Yu, C. Yang, L. Tian, D. Liao: A Study on Optimum Insulation Thicknesses of External Walls in Hot Summer and Cold Winter Zone of China. Applied Energy, 86 Issue 11, Nov (2009) pp. 2520-2529

[13] A. Uçar, F. Balo: "Determination of the Energy Savings and the Optimum Insulation Thickness in the Four Different Insulated Exterior Walls". Renew Energy, 35 (2010), pp. 88-94

[14] Imrich Bartal, Hc László Bánhidi, László Garbai: ”Analysis of the Static Thermal Comfort Equation" Energy and Buildings Vol. 49 (2012) pp. 188191

[15] Garbai L., Jasper A.: "A matematikai rendszerelmélet feldolgozása és alkalmazása épületgépészeti optimalizációs feladatok megoldására"; Magyar Épületgépészet LX. évfolyam, 2011/3. szám, pp. 3-6

[16] Nyers J., Nyers A.: "COP of Heating-Cooling Systemwith Heat Pump" IEEE International Symposium CFP 1188N-PRT EXPRES 2011. Proceedings, pp. 17-21, Subotica, Serbia. 11-12 03. 2011

[17] László Garbai, Szabolcs Méhes: "The Amount of Extractable Heat with Single U-Tube in the Function of Time" Periodica Polytechnica, 52/2 (2008) pp. 49-56, DOI: 10.3311/pp.me.2008-2.02 